\title{
PERAN CAGAR BIOSFER CIBODAS DALAM PENYERAPAN $\mathrm{CO}_{2}$ (The Role of Cibodas Biosphere Reserves in Absorbing $\mathrm{CO}_{2}$ )
}

\author{
Ole/By: \\ Retno Larasati ${ }^{1)}$, Tania June ${ }^{1)} \mathrm{dan} /$ and Sonya Dewi ${ }^{2)}$ \\ ${ }^{1)}$ Departemen Geofisika dan Meteorologi, FMIPA-IPB \\ Gedung FMIPA, Jl. Meranti Wing 19 Lv. Kampus IPB Darmaga, Bogor 16680 \\ Telp/Fax. (0251) 8623850 \\ ${ }^{2)}$ World Agroforestry Center (ICRAF) \\ Jl. CIFOR, Situ Gede Sindang Barang, Bogor 16115 \\ Telp. (0251) 8625415, Fax. (0251) 8625416 \\ Diterima : 6 Maret 2012; Disetujui : 23 April 2012
}

\begin{abstract}
Biosphere reserves are protected areas which the existence is well known globally as an area for promoting the balance relationship between buman beings and the environment. Biosphere reserves have three zones namely the core zone as conservation areas, the buffer zones as a protective area of the core zone, and the transition zones that are intended for regional sustainable development. Cibodas Biosphere Reserve is one of the seve existing biosphere reserves in Indonesia with the largest mountains rain forest ecosystem. One of the environmental services provided by the Cibodas Biosphere Reserve is the ability to absorb $\mathrm{CO}_{2}$. The objective of this study is to estimate the value of the absorption of $\mathrm{CO}_{2}$ in Cibodas Biosphere Reserves using carbon flux value indicated by the value of NPP. The results of this study provide the bighest value of carbon flux in the core zone, buffer zone and transition zone occurred in 2006 that is equal to 1.689,2 $\mathrm{gC} / \mathrm{m}^{2} /$ year, $1.543,4 \mathrm{gC} / \mathrm{m}^{2} /$ year and $1.197,3 \mathrm{gC} / \mathrm{m}^{2} /$ year, consecutively. The highest total potential of $\mathrm{CO}_{2}$ absorption in the core zone occured in 2006 reached 1.473.572,4 tons/year, at the buffer zone occured in 2006 reached 705.096,4 tons/year, and the transition zone occurred in 1991 reached 1.036.069,6 tons/year.
\end{abstract}

Keywords: Biosphere reserves, carbon flux, $\mathrm{CO}_{2}$ absorption

\begin{abstract}
ABSTRAK
Cagar biosfer merupakan kawasan konservasi yang keberadaanya diakui secara internasional sebagai suatu kawasan yang mempromosikan keseimbangan hubungan antara manusia dan lingkungan. Cagar biosfer memiliki 3 zona yakni zona inti sebagai kawasan konservasi, zona penyangga sebagai kawasan pelindung zona inti, serta zona transisi yang diperuntukan bagi kawasan pembangunan berkelanjutan. Cagar Biosfer Cibodas merupakan salah satu dari tujuh cagar biosfer yang ada di Indonesia dengan ekosistem terbesar hutan hujan pegunungan. Salah satu jasa lingkungan yang diberikan oleh Cagar Biosfer Cibodas adalah kemampuannya dalam penyerapan $\mathrm{CO}_{2}$. Penelitian ini bertujuan untuk menduga nilai penyerapan $\mathrm{CO}_{2}$ di Cagar Biosfer Cibodas menggunakan nilai fluks karbon yang ditunjukkan oleh nilai Net Primary Production (NPP). Hasil dari penelitian ini memberikan nilai fluks karbon tertinggi pada zona inti, zona penyangga dan zona transisi terjadi pada tahun 2006 yaitu berturut-turut sebesar 1.689,2 $\mathrm{gC} / \mathrm{m}^{2} /$ tahun, $1.543,4 \mathrm{gC} / \mathrm{m}^{2} /$ tahun dan $1.197,3 \mathrm{gC} / \mathrm{m}^{2} /$ tahun. Potensi total penyerapan $\mathrm{CO}_{2}$ pada zona inti tertinggi terjadi pada tahun 1991 sebesar 1.473.572,4 ton/tahun, pada zona penyangga terjadi pada tahun 2006 sebesar 705.096,4 ton/tahun, dan pada zona transisi terjadi pada tahun 1991 sebesar 1.036.069,6 ton/tahun.
\end{abstract}

Kata kunci: Cagar biosfer, karbon fluks, penyerapan $\mathrm{CO}_{2}$

\section{PENDAHULUAN}

Cagar biosfer didefinisikan dalam UU No 5 tahun 1990 sebagai suatu kawasan yang terdiri dari ekosistem asli, ekosistem unik, dan atau ekosistem yang telah mengalami degradasi yang keseluruhan unsur alamnya dilindungi dan dilestarikan bagi kepentingan penelitian dan pendidikan. Keunikan dari cagar biosfer adalah bahwa kawasan ini secara internasional diakui sebagai kawasan konservasi 
yang dapat mempromosikan keseimbangan hubungan antara manusia dan alam (UNESCO, 2003).

Cagar biosfer sebagai kawasan konservasi memiliki zonasi wilayah yang memiliki fungsi sesuai peruntukannya. Menurut Soedjito (2004) zonasi wilayah itu terdiri dari: (i) zona inti sebagai kawasan lindung dengan luas yang memadai, mempunyai perlindungan hukum jangka panjang, untuk melestarikan keanekaragaman hayati beserta ekosistemnya, (ii) zona penyangga yang berfungsi untuk melindungi area inti dari dampak negatif kegiatan manusia, dimana hanya kegiatan-kegiatan yang sesuai dengan tujuan konservasi yang dapat dilakukan, dan (iii) zona transisi yang berfungsi untuk mempromosikan model-model pembangunan yang berkelanjutan (Man and Biosphere (MAB) Indonesia, 2011).

Indonesia memiliki tujuh cagar biosfer yang telah diakui oleh badan PBB United Nation Educational, Scientific, And Cultural Organization (UNESCO). Ketujuh cagar biosfer itu adalah Cagar Biosfer Siberut di Provinsi Sumatera Barat, Cagar Biosfer Leuser di Provinsi Nangroe Aceh Darusalam (NAD) dan Provinsi Sumatera Utara, Cagar Biosfer Cibodas di Provinsi Jawa Barat, Cagar Biosfer Tanjung Puting di Provinsi Kalimantan Tengah, Cagar Biosfer Lorelindu di Provinsi Sulawesi Tengah, dan Cagar Biosfer Komodo di Provinsi Nusa Tenggara Timur, serta cagar biosfer terbaru yang disetujui UNESCO tahun 2009 yaitu Cagar Biosfer Giam Siak Kecil-Bukit Batu di Provinsi Riau. Masing-masing cagar biosfer ini memiliki keunikan dan kekhasannya tersendiri. Sebagai contoh Cagar Biosfer Cibodas yang berada di tiga kabupaten yakni Kabupaten Cianjur, Kabupaten Sukabumi, dan Kabupaten Bogor penting keberadaannya karena letaknya yang berada di daerah penyangga ibukota negara. Keseimbangan hubungan antara pembangunan daerah penyangga ibukota yang semakin pesat dengan pelestarian lingkungan dipertaruhkan di cagar biosferini.

Cagar Biosfer Cibodas memiliki beberapa potensi jasa lingkungan, diantaranya adalah kemampuannya dalam menyerap karbon (carbon sequestration). Penyerapan karbon menjadi penting berhubungan dengan upaya mitigasi perubahan iklim. Penurunan emisi karbon bukan suatu usaha yang mudah, diperlukan peningkatan usaha konservasi agar terjadi penyerapan karbon yang optimum. Penyerapan karbon yang terjadi pada Cagar Biosfer Cibodas tentunya tidak hanya sebatas wilayah inti yang dalam kasus Cagar Biosfer Cibodas sekaligus merupakan Taman Nasional Gunung Gede Pangrango, namun dapat juga terjadi pada zona penyangga dan transisi di Cagar Biosfer Cibodas.

Di lain pihak, pembangunan yang terjadi pada ketiga zonasi Cagar Biosfer Cibodas tentunya dapat mendorong terjadinya emisi yang mempengaruhi dinamika karbon yang terjadi di wilayah ini. Hal ini yang menyebabkan perubahan keseimbangan karbon yang ada di wilayah Cagar Biosfer Cibodas. Keseimbangan karbon akan berubah seiring dengan terjadinya pembangunan yang tidak disertai dengan upaya konservasi lahan. Oleh karena itu, dalam penelitian ini akan dilakukan pendugaan terhadap potensi penyerapan $\mathrm{CO}_{2}$ di Cagar Biosfer Cibodas antara tahun 1991 2010. Pendugaan potensi penyerapan $\mathrm{CO}_{2}$ ini dilakukan dengan menggunakan nilai fluks karbon yang digambarkan dengan nilai Net Primary Production (NPP). Pengetahuan tentang potensi penyerapan $\mathrm{CO}_{2}$ di wilayah Cagar Biosfer Cibodas diharapkan dapat menjadi salah satu pertimbangan untuk menentukan kebijakan konservasi di setiap zona Cagar Biosfer Cibodas khususnya dan kawasan konservasi lain di Indonesia agar usaha menyeimbangkan karbon berjalan dengan lebih baik.

\section{BAHAN DAN METODE}

\section{A. Kondisi Umum Lokasi}

Cagar Biosfer Cibodas (Gambar 1) ditunjuk tahun 1977 dengan area inti TNGP seluas 15,196 ha yang ditetapkan pada tahun 1980 (MAB Indonesia 2011). TNGP memiliki keanekaragaman ekosistem yang terdiri dari ekosistem sub Montana, Montana, sub alphin, danau, rawa dan savanna dan memiliki temperatur udara $25^{\circ}-28^{\circ} \mathrm{C}$. Curah hujan rata-rata $3,600 \mathrm{~mm} /$ tahun dengan ketinggian tempat 1,000 - 3,000 mdpl. 


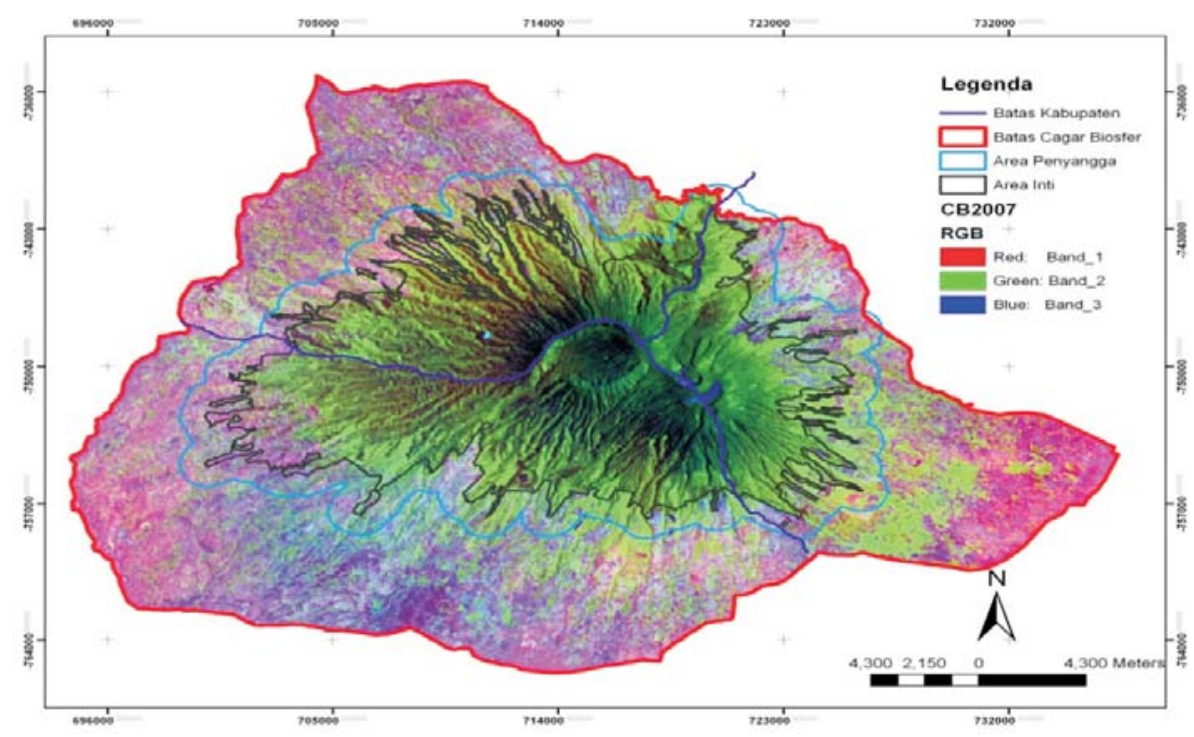

Gambar (Picture) 1. Cagar Biosfer Cibodas (2007) (Cibodas Biosphere Reserves)

\section{B. Tempat dan Waktu}

Penelitian ini dilaksanakan pada bulan Februari sampai dengan Desember tahun 2011, bertempat di Laboratorium Agrometeorologi, Departemen Geofisika dan Meteorologi, FMIPA-IPB.

\section{Data dan Peralatan}

Data yang digunakan dalam penelitian ini berupa:

1. Data observasi bulanan curah hujan $(\mathrm{CH})$, suhu maksimum $\left(\mathrm{T}_{\max }\right)$, suhu minimum $\left(\mathrm{T}_{\min }\right)$, suhu rata-rata $\left(\mathrm{T}_{\text {mean }}\right)$, dan intensitas radiasi Stasiun Meteorologi Pacet periode data 1 Januari 1990 31 Desember 2010. (BALITKLIMAT).

2. Data citra Landsat TM/ETM+ path/row 122/65, dengan aquisisi 28 Juli 1991, 12 Mei 2001, 18 Mei 2006, dan 21 Mei 2010 dari website NOAA: http://www.usgs.gov/

Analisis data dalam studi ini menggunakan perangkat lunak ERDAS IMAGINE 9.1 dan Arc View GIS 3.3 untuk pengolahan data citra, serta Microsoft Office 2007.

\section{Metode Penelitian}

Pendugaan potensi penyerapan $\mathrm{CO}_{2}$ di Cagar Biosfer Cibodas dilakukan dengan terlebih dahulu menduga nilai NPP. Pendugaan nilai NPP dilakukan dengan menggunakan data citra Landsat, Data iklim, dan nilai efisiensi penggunaan radiasi matahari (e). Data citra Landsat digunakan untuk memperoleh nilai NDVI yang kemudian diturunkan untuk mendapatkan nilai fAPAR sebagai salah satu faktor untuk memperoleh nilai NPP.

1. Data Intensitas Radiasi

Data radiasi yang diperoleh dari Stasiun Meteorologi Pacet diubah satuannya ke dalam satuan $\mathrm{MJ} / \mathrm{m}^{2} /$ hari atau $\mathrm{MJ} / \mathrm{m}^{2} /$ bulan jika belum dalam keadaan satuan tersebut.

\section{Menentukan Nilai $\operatorname{PAR}_{\mathrm{i}}$}

Nilai PAR income $\left(\mathrm{PAR}_{\mathrm{i}}\right)$ diperoleh dari unsur unsur iklim seperti radiasi surya dan temperatur udara. Perhitungan nilai $\mathrm{PAR}_{\mathrm{i}}$ menurut June (2002) dalam Churniawan (2008) digambarkan sebagai berikut:

$\operatorname{PAR}_{\mathrm{i}}\left(\mathrm{MJ} / \mathrm{m}^{2} /\right.$ bulan $)=0,5 \mathrm{X}$ total radiasi global (MJ $/ \mathrm{m}^{2} /$ bulan)

\section{Klasifikasi Terbimbing}

Klasifikasi unsur tutupan lahan menggunakan bantuan data hasil survei identifikasi unsur di lapangan (ground chek) dan bantuan dari peta tutupan lahan wilayah Cagar Biosfer Cibodas dari Balai Besar Taman Nasional Gunung Gede Pangrango tahun 2004, sehingga diperoleh hubungan antara nilai piksel pada citra dengan unsur yang telah diidentifikasi. 


\section{Menentukan Nilai NDVI}

Pengolahan data citra satelit untuk mendapatkan nilai NDVI dilakukan dengan menggunakan perangkat lunak ERDAS IMAGINE 9.0. Sebelum melakukan perhitungan NDVI, terlebih dahulu dilakukan koreksi radiometrik dan koreksi geometrik yang bertujuan untuk mendapatkan kenampakan yang jelas dan akurat terhadap koordinat bumi yang sebenarnya. Setelah data sudah terkoreksi, kemudian dilakukan perhitungan NDVI (Lillisand dan Kiefer 1997) sebagai berikut:

(Band 4 - Band 3)

NDVI $=$

(Band $4+$ Band 3)

\section{Dimana:}

Band $4=$ Nilai reflektansi dari band cahaya inframerah dekat

Band $3=$ Nilai reflektansi dari band cahaya merah

Setelah semua tutupan lahan diketahui nilai NDVI-nya, kemudian mencari nilai NDVI setiap wilayah zonasi Cagar Biosfer Cibodas, dengan melakukan cropping pada citra satelit Landsat berdasarkan zonasi cagar biosfernya tiap tahun kajian.

\section{Menentukan Nilai fAPAR}

Nilai fAPAR diduga dengan mengggunakan persamaan fAPAR yang diperoleh dari penelitian Ochi and Shibasaki (1999) dalam June (2006) di Taman Nasional Lorelindu. Persamaan ini digunakan karena sifat wilayah kajian yang paling mendekati Cagar Biosfer Cibodas dimana Taman Nasional Lorelindu merupakan salah satu wilayah hutan hujan pegunungan di Indonesia. Persamaan yang digunakan yaitu sebagai berikut:

$$
\text { fAPAR }=-0,08+1,075 \text { NDVI }
$$

\section{Menentukan Nilai Efisiensi Radiasi (e)}

Efisiensi penggunaan radiasi (e) diperoleh berdasarkan metode akumulasi biomassa $\left(\mathrm{gMJ}^{-1}\right.$; Monteith, 1977 dalam Rusmayadi et al., 2008) yang merupakan nisbah antara akumulasi bahan kering di atas tanah $\left(\mathrm{W}_{\mathrm{gmm}}{ }^{-2}\right)$ dan intersepsi radiasi $\left(\mathrm{Q}_{\text {int }}, \mathrm{MJ}\right.$ $\mathrm{m}^{-2}$ ) dari proporsi radiasi yang ditransmisikan ke permukaan tanah.

$$
\mathrm{e}=\mathrm{W} / \mathrm{Q}_{\mathrm{int}}
$$

Pada penelitian ini nilai e yang digunakan adalah rata-rata nilai e berdasarkan hasil studi literatur yakni sebesar 1,30 $\mathrm{g} \mathrm{MJ}^{-1}$ (Ibrom et al., 2007; ORNL DAAC dalam Supeni, 2006; June, 2004 dalam Supeni, 2006; Kusumaningrum, 2003 dalam Lestariningsih, 2006; Ochi dan Murai, 2000 dalam Supeni, 2006; Hirakoba et al., 1977 dalam Lestariningsih, 2006).

\section{Menentukan Nilai NPP}

Nilai NPP diperoleh dari modifikasi persamaan Monteith (1972) dalam June et al. (2006) . Persamaan tersebut adalah :

$$
\operatorname{NPP}\left(\mathrm{gC} / \mathrm{m}^{2} / \text { tahun }\right)=\Sigma\left(\mathrm{e} * \mathrm{fAPAR}^{*} \operatorname{PAR}_{\mathrm{i}}\right)
$$

8. Menentukan Nilai Penyerapan $\mathrm{CO}_{2}$

Nilai penyerapan $\mathrm{CO}_{2}$ diperoleh dengan persamaan sebagai berikut:

$$
\text { Penyerapan } \mathrm{CO}_{2}=\mathrm{NPP} \times \text { Luas }_{\mathrm{x}} \text { 3,67 }
$$

Dimana:

Penyerapan $\mathrm{CO}_{2}$ dalam ton/tahun; Luas dalam $\mathrm{m}^{2}$ dan 3,67 adalah faktor konversi $\mathrm{C}$ ke $\mathrm{CO}_{2}$.

\section{HASIL DAN PEMBAHASAN}

\section{A. Keadaan Iklim Cagar Biosfer Cibodas}

Data klimatologi yang digunakan adalah data dari Stasiun Meteorologi Pacet dari BALITKLIMAT. Stasiun Meteorologi Pacet memiliki ketinggian 1138 meter diatas permukaan laut dengan koordinat lintang dan bujur berturut-turut sebesar $6^{\circ} 45^{\prime}$ Lintang Selatan dan $107^{\circ}$ 02' Bujur Timur. Hasil pengolahan data iklim ini adalah nilai intensitas radiasi, suhu udara, dan curah hujan ratarata bulanan selama tahun 1990 sampai dengan tahun 2010.

Pada bulan Februari nilai intensitas radiasi merupakan nilai intensitas radiasi yang terendah yakni sebesar $284 \mathrm{MJ} / \mathrm{m}^{2} /$ bulan, sedangkan pada bulan September nilai intensitas radiasi berada di nilai yang tertinggi yakni sebesar $490 \mathrm{MJ} / \mathrm{m}^{2} /$ bulan. Pola yang terbentuk dari data suhu udara Stasiun Meteorologi Pacet menyerupai intensitas radiasi, dimana pada bulan Februari nilai suhu 
udara berada pada posisi terendah dengan nilai sebesar $20,8^{\circ} \mathrm{C}$ dan bulan September merupakan titik dimana suhu udara memiliki posisi tertinggi dengan nilai suhu udara sebesar $22,1^{\circ} \mathrm{C}$. Curah hujan memiliki pola yang berbeda dari dua data iklim sebelumnya. Pada nilai curah hujan, posisi tertinggi dari data adalah pada bulan November dengan nilai curah hujan sebesar $413 \mathrm{~mm}$ dan posisi terendah berada pada bulan Juli yakni sebesar $114 \mathrm{~mm}$.

\section{B. Tutupan Lahan Cagar Biosfer Cibodas}

Luas total Cagar Biosfer Cibodas berdasarkan hasil pengolahan data luas lahan adalah sebesar 77.656 ha, sedangkan luas total zona inti, zona penyangga, dan zona transisi Cagar Biosfer Cibodas berturut-turut sebesar 23.791 ha atau sekitar 31\% dari luas total Cagar Biosfer Cibodas, 14.385 ha $(18 \%)$, dan 39.480 ha (51\%). Luas tutupan lahan oleh hutan cenderung stabil selama tahun 1991 hingga tahun 2010 dengan luas sekitar 18.000 ha di zona inti, 3.600 ha di zona penyangga, dan 1.600 ha di zona transisi.

Luas hutan di zona inti yang cenderung stabil antar tahun dipengaruhi oleh keberadaan zona inti Cagar Biosfer Cibodas sebagai kawasan konservasi aktif yang dilindungi oleh undang-undang, Taman Nasional Gunung Gede Pangrango. Kecenderungan luas hutan stabil antar tahun di zona penyangga dan zona transisi namun mengalami penurunan luas antar zona. Hal ini karena pada zona penyangga terjadi konversi lahan yang tidak sesuai peruntukan, seperti adanya pembangunan di zona penyangga Cagar Biosfer Cibodas menjadi kawasan wisata Taman Safari Indonesia dan Kebun Raya Cibodas beserta bangunan pendukung lainnya di kawasan tersebut. Pada zona transisi terjadi konversi lahan vegetasi menjadi lahan non vegetasi yang sangat tinggi dibandingkan dua zona lain, hal ini tidak terlepas dari fungsi zona transisi sendiri sebagai kawasan pembangunan di Cagar Biosfer Cibodas.
Pada tahun 2001, terjadi perubahan luas yang besar pada tutupan lahan oleh pertanian lahan kering atau ladang. Pada zona inti, selama tahun 1991 hingga tahun 2001 luas ladang mengalami kenaikan sebesar 292 ha, sedangkan pada zona penyangga dan zona transisi peningkatannya berturut-turut sebesar 1.961 ha dan 5.026 ha. Luas tutupan lahan oleh ladang juga cenderung mengalami peningkatan selama tahun 2001 hingga tahun 2010, namun peningkatannya tidak sebesar yang terjadi antara tahun 1991 hingga tahun 2001. Salah satu faktor Pemicu peningkatan luas ladang pada tahun 2001 adalah penjarahan lahan yang dilakukan oleh masyarakat terhadap PT. Perkebunan Nusantara VIII selama era reformasi tahun 1997. Lahan perkebunan hasil penjarahan oleh masyarakat sebagian besarnya di konversi menjadi ladang (Suheri, 2003).

Setelah tahun 2001, kawasan Cagar Biosfer Cibodas cenderung melakukan perbaikan lahan. Hal ini bisa dilihat dari adanya usaha rehabilitasi lahan yang dilakukan sejak tahun 2004 oleh Balai Besar Taman Nasional Gunung Gede Pangrango. Rehabilitasi lahan yang dilakukan menyebabkan peningkatan luas untuk tutupan lahan semak/ belukar berupa tanaman atau tumbuhan muda (Balai Besar Taman Nasional Gunung Gede Pangrango, 2012). Peningkatan luas semak/ belukar berdasarkan hasil klasifikasi lahan antara tahun 2001 hingga 2006 mengalami peningkatan baik di zona inti, zona penyangga, maupun zona transisi. Pada zona inti, terjadi peningkatan sebesar 1.242 ha dan di zona penyangga serta zona transisi peningkatan luasnya berturut-turut sebesar 1.567 ha dan 198 ha.

\section{Normalized Difference Vegetation Index (NDVI)}

Kisaran nilai NDVI pada penelitian ini memiliki nilai antara 0 - 0,99. Kisaran ini menunjukkan kondisi dari vegetasi yang berada pada Cagar Biosfer Cibodas. Kondisi vegetasi yang baik akan memiliki kisaran nilai NDVI yang tinggi. 

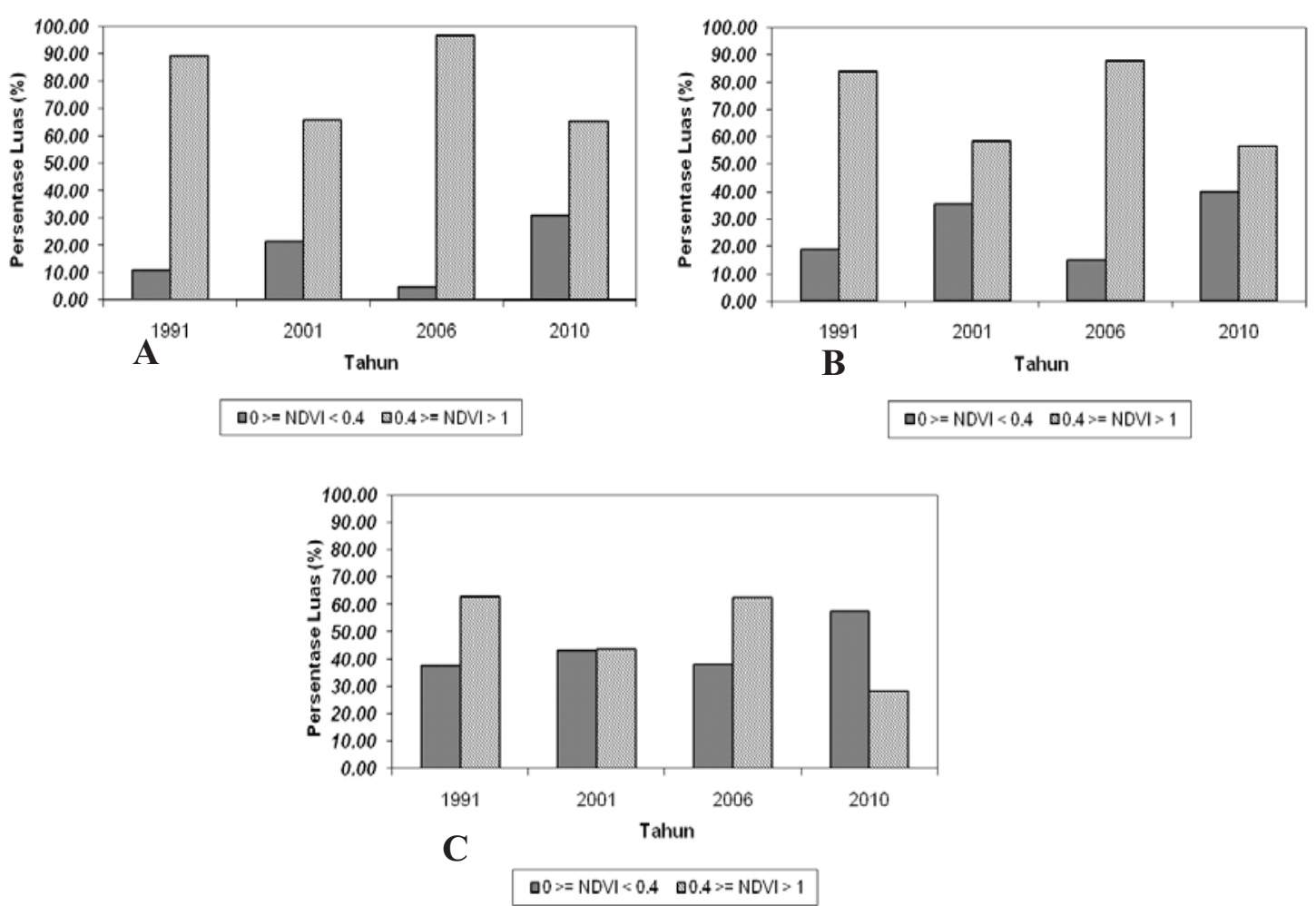

Gambar (Figure) 2. Grafik sebaran nilai NDVI berdasarkan luas : A. zona inti ; B. zona penyangga; C. zona transisi Cagar Biosfer Cibodas dengan nilai threshold 0,4 (The distribution chart of NDVI value by area: A. core zone; B. buffer zone; C. transition zone of the Cibodas Biosphere Reserves threshold value 0,4)

Berdasarkan hasil pengolahan data NDVI pada penelitian ini, kisaran nilai NDVI antara 0 - 0,1 sebagian besar merupakan awan, bayangan awan, lahan terbangun, juga sebagian badan air. Kisaran nilai NDVI antara 0,1 - 0,2 menggambarkan kondisi vegetasi di sekitar lahan terbangun. Kisaran nilai NDVI antara 0,2 - 0,3 menggambarkan kondisi vegetasi pada lahan pertanian seperti sawah dan kisaran nilai NDVI antara 0,3 - 0,4 menggambarkan kondisi vegetasi pada pertanian lahan kering seperti ladang. Kisaran NDVI antara 0,4- 1 menggambarkan kondisi vegetasi yang memiliki kerapatan yang cukup tinggi hingga menggambarkan kondisi vegetasi hutan.

Gambar 2 memperlihatkan sebaran nilai NDVI berdasarkan persentase luas zona Cagar Biosfer Cibodas dengan nilai threshold 0,4. Pada zona inti sebaran nilai NDVI di atas nilai threshold paling tinggi di semua tahun kajian dan semakin menurun ke zona penyangga dan memiliki sebaran yang paling kecil di zona transisi. Hal ini membuktikan bahwa kondisi vegetasi pada zona inti merupakan kondisi vegetasi terbaik pada Cagar Biosfer Cibodas dan kondisi vegetasi semakin menurun ke zona penyangga dan zona transisi.

\section{Fraction of Photosyntbetically Active Radiation (fAPAR)}

fAPAR merupakan salah satu komponen penting dalam pendugaan NPP. Nilai fAPAR menggambarkan aktivitas fotosintesis yang dilakukan oleh kanopi vegetasi. Hasil akhir pengolahan nilai NDVI digunakan untuk memprediksi nilai fAPAR, sehingga nilai fAPAR merupakan turunan dari nilai NDVI. Berdasarkan hasil pengolahan data didapatkan kisaran nilai fAPAR antara 0 - 0,99. Kisaran nilai fAPAR menggambarkan kondisi vegetasi yang serupa dengan kisaran nilai NDVI. 

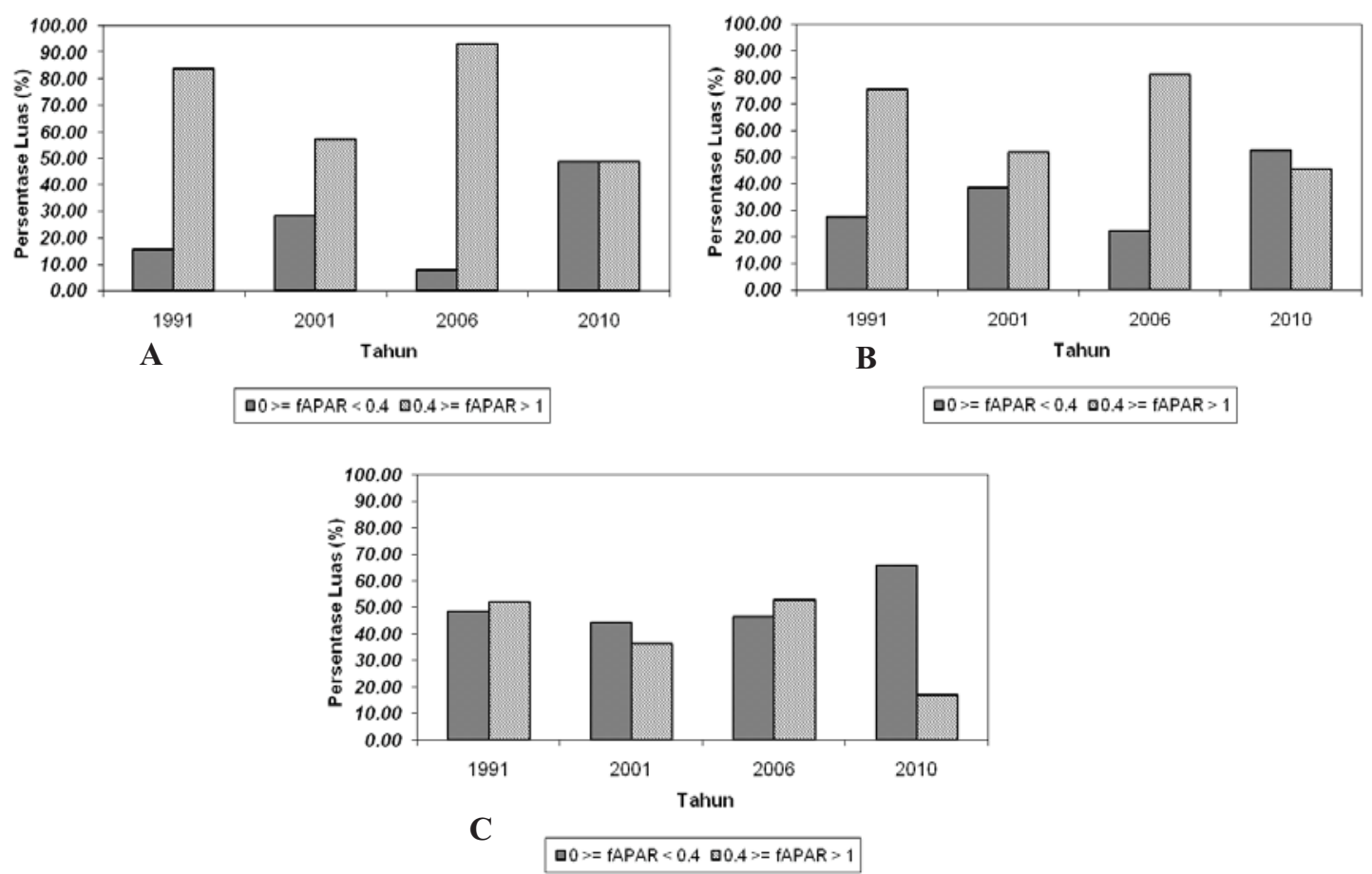

Gambar (Figure) 3. Grafik sebaran nilai fAPAR berdasarkan luas : A. zona inti; B. zona penyangga; C. zona transisi Cagar Biosfer Cibodas dengan nilai threshold 0,4 (The distribution chart of $f A P A R$ value by area: A. core zone; B. buffer zone; $C$. transition zone of the Cibodas Biosphere Reserves threshold value 0,4)

Seperti halnya yang terjadi pada sebaran nilai NDVI, Gambar 3 juga memperlihatkan sebaran nilai fAPAR berdasarkan luas zona Cagar Biosfer Cibodas dengan nilai threshold 0,4. Pada zona inti sebaran nilai fAPAR di atas nilai threshold memiliki nilai yang paling tinggi dibandingkan dengan zona lainnya. Hal ini menjelaskan bahwa kanopi vegetasi pada zona inti paling besar melakukan fotosintesis dibandingkan dengan vegetasi di zona lain.

\section{E. Net Primary Production (NPP)}

Kisaran nilai NPP menggambarkan fluktuasi produksi hasil fotosintesis tanaman/tumbuhan setelah dikurangi hasil produksi yang dipakai dalam proses respirasi tanaman/tumbuhan tersebut. Fluktuasi nilai NPP rata - rata selama empat tahun kajian diperlihatkan pada Gambar 4. Perubahan nilai NPP berdasarkan hasil pendugaan pada penelitian ini menunjukkan perubahan vegetasi (baik luasan atau kondisi). Hal ini dikarenakan, pendugaan NPP menggunakan nilai NDVI dan nilai fAPAR yang diturunkan dari nilai NDVI. Kondisi vegetasi rapat memiliki nilai NDVI dan fAPAR yang besar sehingga akan memiliki nilai pendugaan NPP yang juga besar. Berdasarkan zonasi wilayah Cagar Biosfer Cibodas, zona inti memiliki nilai NPP yang paling besar dibandingkan dengan zona lain. Nilai NPP semakin menurun ke zona penyangga dan nilai NPP yang paling rendah berada di zona transisi. Persentase luas dari kisaran nilai NDVI dan fAPAR akan mempengaruhi nilai NPP di Cagar Biosfer Cibodas. 
Tabel 1. Nilai NPP berdasarkan zonasi dalam Cagar Biosfer Cibodas tahun 1991 - 2010

Table 1. NPP value on the zoning in Cibodas Biosphere Reserves in $1991-2010$

\begin{tabular}{|c|c|c|c|c|c|c|}
\hline $\begin{array}{l}\text { Tahun } \\
\text { (Year) }\end{array}$ & $\begin{array}{l}\text { Zona } \\
\text { (Zone) }\end{array}$ & e (g/MJ) & NDVI & fAPAR & $\begin{array}{c}\mathrm{PAR}_{\mathrm{i}} \\
\left(\mathrm{MJ} / \mathrm{m}^{2} / \text { tahun }\right)\end{array}$ & $\begin{array}{c}\mathrm{NPP} \\
\left(\mathrm{gC} / \mathrm{m}^{2} / \text { tahun }\right)\end{array}$ \\
\hline \multirow{3}{*}{1991} & $\begin{array}{l}\text { Inti } \\
\text { (Core) }\end{array}$ & \multirow{3}{*}{1,30} & 0,531 & 0,495 & 2.241 & $1.442,6$ \\
\hline & $\begin{array}{c}\text { Penyangga } \\
\text { (Buffer) }\end{array}$ & & 0,506 & 0,465 & 2.241 & $1.355,3$ \\
\hline & $\begin{array}{c}\text { Transisi } \\
\text { (Transition) }\end{array}$ & & 0,435 & 0,389 & 2.241 & $1.132,7$ \\
\hline \multirow{3}{*}{2001} & $\begin{array}{l}\text { Inti } \\
\text { (Core) }\end{array}$ & \multirow{3}{*}{1,30} & 0,480 & 0,444 & 2.413 & $1.392,3$ \\
\hline & $\begin{array}{c}\text { Penyangga } \\
\text { (Buffer) }\end{array}$ & & 0,436 & 0,407 & 2.413 & $1.271,1$ \\
\hline & $\begin{array}{c}\text { Transisi } \\
\text { (Transition) }\end{array}$ & & 0,380 & 0,356 & 2.413 & $1.117,4$ \\
\hline \multirow{3}{*}{2006} & $\begin{array}{c}\text { Inti } \\
\text { (Core) }\end{array}$ & \multirow{3}{*}{1,30} & 0,580 & 0,545 & 2.386 & $1.689,2$ \\
\hline & $\begin{array}{c}\text { Penyangga } \\
\text { (Buffer) }\end{array}$ & & 0,537 & 0,498 & 2.386 & $1.543,4$ \\
\hline & $\begin{array}{c}\text { Transisi } \\
\text { (Transition) }\end{array}$ & & 0,429 & 0,386 & 2.386 & $1.197,3$ \\
\hline \multirow{3}{*}{2010} & $\begin{array}{l}\text { Inti } \\
(\text { Core }) \\
\end{array}$ & \multirow{3}{*}{1,30} & 0,438 & 0,459 & 2.330 & $1.144,7$ \\
\hline & $\begin{array}{c}\text { Penyangga } \\
\text { (Buffer) }\end{array}$ & & 0,417 & 0,464 & 2.330 & $1.083,9$ \\
\hline & $\begin{array}{c}\text { Transisi } \\
\text { (Transition) }\end{array}$ & & 0,316 & 0.443 & 2.330 & 797,9 \\
\hline
\end{tabular}

Nilai NPP di zona inti lebih tinggi dibandingkan dengan zona lain, hal ini dipengaruhi oleh keberadaan zona inti Cagar Biosfer Cibodas sebagai kawasan konservasi aktif yakni Taman Nasional Gunung Gede Pangrango. Pada zona ini kondisi vegetasi masih terjaga dengan baik dan usaha-usaha konversi lahan vegetasi menjadi lahan non vegetasi sangat dihindari. Terbukti dengan hasil klasifikasi lahan di zona inti bahwa luas vegetasi hutan semenjak tahun 1991 hingga 2010 di zona inti Cagar Biosfer Cibodas relatif stabil berkisar antara 18.000 ha atau $76 \%$ dari luas total zona inti.

Penurunan nilai NPP di zona inti terjadi selama tahun 1991 hingga 2001 sebesar $50,3 \mathrm{gC} / \mathrm{m}^{2} /$ tahun. Penurunan nilai NPP pada tahun 2001 disebabkan karena adanya perluasan tanaman pertanian lahan kering berupa ladang. Luas ladang pada tahun 2001 mengalami kenaikan sebesar 39\% dari luas ladang tahun 1991.

Pada tahun 2006 nilai NPP zona inti mengalami peningkatan sebesar $297 \mathrm{gC} / \mathrm{m}^{2} /$ tahun dari tahun 2001. Peningkatan nilai NPP terjadi karena pada tahun 2006 terjadi perbaikan kondisi vegetasi karena adanya upaya rehabilitasi lahan sejak tahun 2004 (Balai Besar TNGP, 2012). Pada tahun 2010 nilai NPP mengalami penurunan sebesar 544,6 $\mathrm{gC} / \mathrm{m}^{2} /$ tahun dari nilai NPP zona inti pada tahun 2006. Hal ini disebabkan karena pada tahun 2010 luas tutupan lahan ladang merupakan luas ladang terbesar di zona inti dibandingkan dengan tahun kajian lain. Luas ladang pada tahun 2010 di zona inti mengalami kenaikan sebesar 547,4 ha dari tahun 2006. 


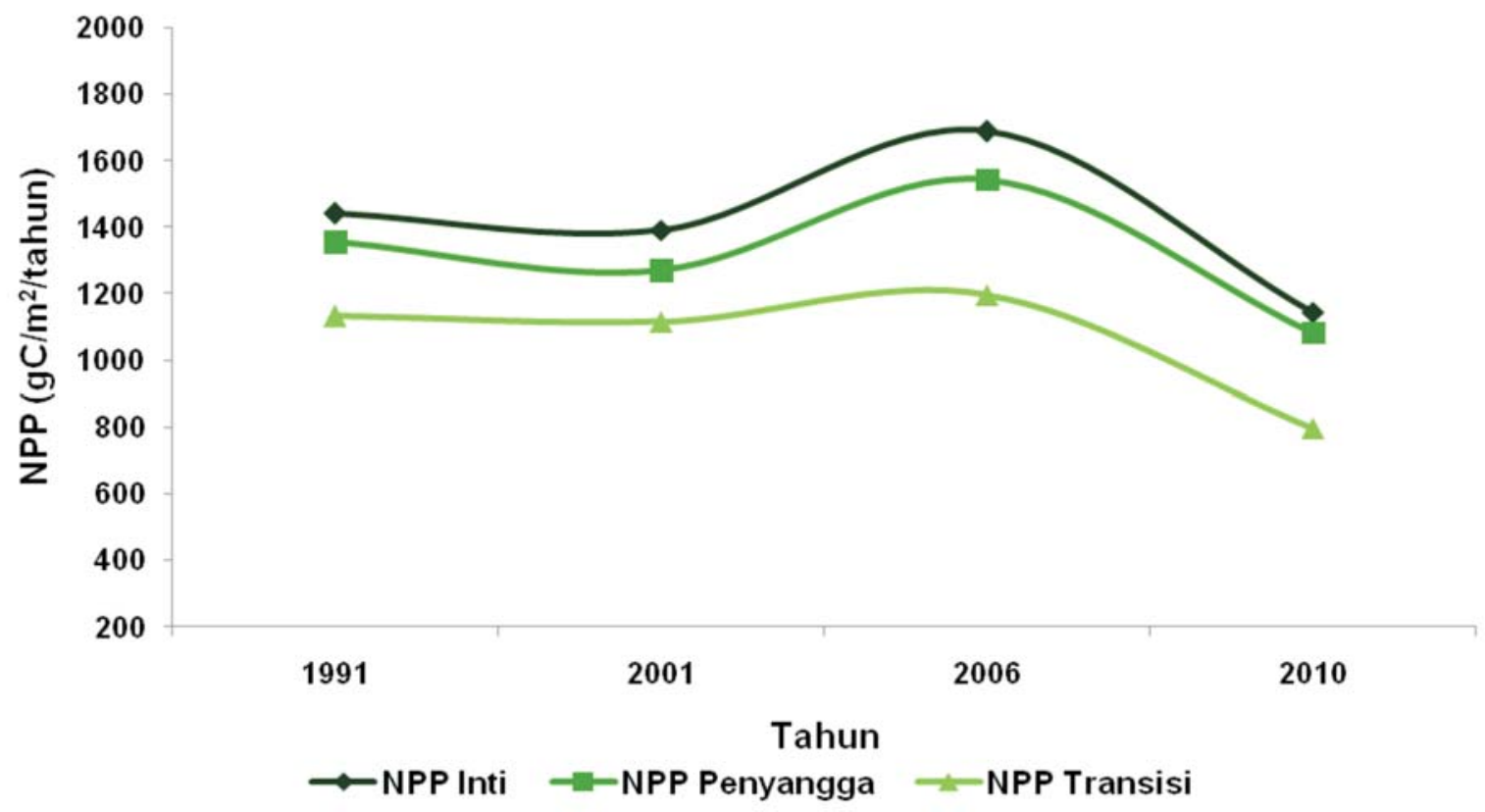

Gambar 4. Grafik distribusi nilai NPP berdasarkan zonasi dalam Cagar Biosfer Cibodas tahun 1991 - 2010 Figure 4. The distribution curve of NPP value based on the zoning of Cibodas Biosphere Reserves in 1991-2010

Penurunan nilai NPP pada zona penyangga lebih banyak disebabkan karena perubahan luas lahan vegetasi dan menurunnya luas hutan. Luas hutan di zona penyangga berdasarkan hasil klasifikasi lahan hanya sebesar 3.500 ha atau $25 \%$ dari total luas zona penyangga Cagar Biosfer Cibodas. Seperti yang terjadi pada zona inti, di zona penyangga pun nilai NPP tertinggi terjadi pada tahun 2006 sebesar $1.543,4 \mathrm{gC} / \mathrm{m}^{2} /$ tahun. Nilai NPP di zona penyangga pada tahun 2006 yang lebih tinggi dibandingkan dengan tahun kajian lain disebabkan oleh faktor peningkatan luas semak/belukar berupa tanaman/tumbuhan muda yang meningkat pada zona penyangga di tahun 2006. Luas ladang pada tahun 2006 di zona penyangga mencapai $2.981,8 \mathrm{Ha}$ atau 20\% total luas zona penyangga Cagar Biosfer Cibodas. Luas ladang di tahun kajian lain berkisar antara 7 sampai $10 \%$ lebih tinggi sekitar 11\% dari rata - rata luas semak/belukar di tahun kajian lain.

Nilai NPP terendah pada zona penyangga terjadi di tahun 2010. Terjadi penurunan sebesar 459,5 $\mathrm{gC} / \mathrm{m}^{2} /$ tahun dari nilai NPP tahun 2006. Penurunan nilai NPP pada tahun 2010 lebih disebabkan karena tingginya luas lahan terbangun/lahan terbuka dan adanya konversi lahan vegetasi semak/belukar atau perkebunan menjadi ladang. Berdasarkan hasil klasifikasi lahan, luas lahan terbangun/lahan terbuka di zona penyangga pada tahun 2010 mengalami peningkatan sebesar 636,2 ha dari tahun 2006. Selain itu luas ladang pada tahun 2010 adalah luas ladang terbesar pada zona penyangga selama empat tahun kajian dengan luas sebesar 4.213,8 ha.

Pada zona transisi, konversi lahan vegetasi menjadi lahan non vegetasi banyak terjadi. selain faktor konversi lahan pada zona transisi pun luas vegetasi hutan berkurang sangat besar dibandingkan dengan zona inti. Pada zona transisi luas vegetasi hutan hanya sekitar 1.600 ha atau sekitar $4 \%$ dari luas zona transisi Cagar Biosfer Cibodas. Dua faktor ini yang menyebabkan nilai NPP di zona transisi menjadi lebih rendah dibandingkan dengan zona inti dan zona penyangga.

Nilai NPP selama tahun 1991 hingga 2006 cenderung stabil sekitar 1.149,1 $\mathrm{gC} / \mathrm{m}^{2} /$ tahun, namun pada tahun 2010 nilai NPP mengalami penurunan sebesar 399,4 $\mathrm{gC} / \mathrm{m}^{2} /$ tahun dari nilai NPP tahun 2006 menjadi 797,9 gC/m²/tahun. Hal ini disebabkan karena banyak terjadi konversi lahan vegetasi menjadi lahan non vegetasi. 


\section{F. Potensi Penyerapan $\mathrm{CO}_{2}$ Cagar Biosfer Cibodas}

Hasil pendugaan nilai penyerapan $\mathrm{CO}_{2}$ di Cagar Biosfer Cibodas memasukan unsur luas dalam penghitungannya. Luas yang digunakan dalam menghitung penyerapan $\mathrm{CO}_{2}$ di Cagar Biosfer Cibodas adalah luas untuk lahan vegetasi. Pada zona inti diasumsikan seluruh luas zona inti adalah tutupan lahan vegetasi. Selain karena 98\% luas tutupan lahan zona inti adalah tutupan lahan vegetasi, hal ini dilakukan untuk mengurangi pengaruh dari penutupan awan dan data rusak yang terjadi pada data citra di tahun-tahun kajian tertentu.
Dinamika nilai NPP di zona inti merupakan satu-satunya faktor yang menyebabkan perubahan nilai penyerapan karbon dan $\mathrm{CO}_{2}$ antar tahun kajian di Cagar Biosfer Cibodas. Hal ini karena nilai luas lahan vegetasi di zona inti dibuat sama dan nilai konversi karbon menjadi $\mathrm{CO}_{2}$ sebesar 3,67 sama untuk setiap zona dan tahun kajian. Pada zona inti nilai penyerapan $\mathrm{CO}_{2}$ terbesar terjadi pada tahun 2006 sebesar 1.473.572,4 ton/tahun. Nilai penyerapan $\mathrm{CO}_{2}$ terendah terjadi pada tahun 2010 sebesar 998.526,71ton/tahun. Kecenderungan nilai dugaan penyerapan $\mathrm{CO}_{2}$ di zona inti Cagar Biosfer Cibodas mengikuti pola dari nilai NPP yang telah dibahas sebelumnya.

Tabel 2. Nilai potensi penyerapan $\mathrm{CO}_{2}$ berdasarkan zonasi Cagar Biosfer Cibodas tahun $1991-2010$ Table 2. The value of $\mathrm{CO}_{2}$ sequestration potential based on the zoning of Cibodas Biosphere Reserves in $1991-2010$

\begin{tabular}{|c|c|c|c|c|c|c|}
\hline $\begin{array}{l}\text { Tahun } \\
\text { (Year) }\end{array}$ & $\begin{array}{l}\text { Zona } \\
\text { (Zone) }\end{array}$ & $\begin{array}{c}\text { Luas Area } \\
(\text { Area Width) } \\
(\mathrm{Ha})\end{array}$ & $\begin{array}{c}\text { Luas Area } \\
(\text { Area Width }) \\
\left(\mathrm{m}^{2}\right)\end{array}$ & $\begin{array}{l}\mathrm{NPP} \\
\left(\mathrm{gC} / \mathrm{m}^{2} /\right. \\
\text { tahun) }\end{array}$ & $\begin{array}{l}\text { Potensi penyerapan C } \\
\text { (C Sequestration Potential) } \\
\text { (Ton C/Tahun) }\end{array}$ & $\begin{array}{c}\text { Potensi penyerapan } \mathrm{CO}_{2} \\
\left(\mathrm{CO}_{2} \text { Sequestration Potential) }\right. \\
\text { (Ton/tahun) }\end{array}$ \\
\hline 1991 & & 23.790 & 237.909 .600 & $1.442,6$ & $343.211,8$ & $1.258,442,8$ \\
\hline 2001 & Inti & 23.790 & 237.909 .600 & $1.392,3$ & $331.237,2$ & $1.214,536,3$ \\
\hline 2006 & (Core) & 23.790 & 237.909 .600 & $1.689,2$ & $401.883,4$ & $1.473,572,4$ \\
\hline 2010 & & 23.790 & 237.909 .600 & $1.144,7$ & $272.325,5$ & $998.526,7$ \\
\hline 1991 & & 10.425 & 104.249 .740 & $1.355,3$ & $141.292,6$ & $518.072,7$ \\
\hline 2001 & Penyangga & 11.680 & 116.799 .880 & $1.271,1$ & $148.465,7$ & $544.374,2$ \\
\hline 2006 & (Buffer) & 12.460 & 124.596 .000 & $1.543,4$ & 192.299 & $705.096,4$ \\
\hline 2010 & & 11.543 & 115.434 .500 & $1.083,9$ & $125.121,2$ & $458.777,9$ \\
\hline 1991 & & 24.946 & 249.462 .532 & $1.132,7$ & $282.564,4$ & $1.036 .069,6$ \\
\hline 2001 & Transisi & 23.735 & 237.351 .060 & $1.117,4$ & $265.215,4$ & $972.456,5$ \\
\hline 2006 & (Transition) & 21.797 & 217.971 .000 & $1.197,3$ & $260.983,8$ & $956.940,6$ \\
\hline 2010 & & 20.937 & 209.374 .675 & 797,9 & 167.062 & $612.560,5$ \\
\hline
\end{tabular}

Pada zona penyangga, dimana luasan untuk tutupan lahan vegetasi berbeda setiap tahun, Nilai dari penyerapan $\mathrm{CO}_{2}$ menjadi lebih dinamis dibandingkan dengan zona inti. Nilai penyerapan $\mathrm{CO}_{2}$ pada tahun 2010 sebesar $458.777,9$ ton/tahun merupakan nilai penyerapan terkecil diantara tahun kajian lain di zona yang sama. Selain karena luas tutupan lahan vegetasi yang lebih kecil dibandingkan dengan tahun 2001 dan 2006, pada tahun 2010 nilai NPP merupakan nilai NPP terkecil pada zona penyangga. Nilai dugaan penyerapan $\mathrm{CO}_{2}$ pada tahun 1991 juga kecil disebabkan oleh luas tutupan lahan vegetasi yang lebih rendah. Tutupan lahan vegetasi yang rendah ini disebabkan karena adanya tutupan awan dan bayangan awan pada tahun tersebut yang mengurangi luas lahan vegetasi di tahun yang sama.
Penyerapan $\mathrm{CO}_{2}$ di zona transisi lebih banyak dilakukan oleh tanaman perkebunan dan pertanian lahan kering seperti ladang. Pada zona ini, terjadi dinamika perubahan luas tutupan lahan vegetasi. Selain itu pada zona transisi juga terjadi perubahan nilai NPP antar tahun kajian. Nilai dugaan penyerapan $\mathrm{CO}_{2}$ pada zona transisi cenderung menurun selama tahun 1991 hingga 2010. Nilai penyerapan $\mathrm{CO}_{2}$ terbesar terjadi pada tahun 1991 sebesar 1.036.069,6 ton/tahun. Nilai penyerapan $\mathrm{CO}_{2}$ yang tinggi di tahun ini mengindikasikan bahwa keadaan vegetasi di zona transisi pada tahun 1991 masih baik dibandingkan dengan tahun kajian lain. Hal ini ditandai dengan penurunan nilai penyerapan $\mathrm{CO}_{2}$ yang terus terjadi selama tahun 2001 hinggga 2010. 


\section{KESIMPULAN}

1. Nilai Net Primary Production (NPP) tertinggi masing-masing zona Cagar Biosfer Cibodas adalah sebagai berikut:

- Zona Inti terjadi pada tahun 2006 sebesar $1.689,2 \mathrm{gC} / \mathrm{m}^{2} /$ tahun

- Zona penyangga terjadi pada tahun 2006 sebesar $1.543 .4 \mathrm{gC} / \mathrm{m}^{2} /$ tahun

- Zona transisi terjadi pada tahun 2006 sebesar $1.197,3 \mathrm{gC} / \mathrm{m}^{2} /$ tahun

2. Nilai potensi penyerapan $\mathrm{CO}_{2}$ tertinggi masingmasing zona Cagar Biosfer Cibodas adalah sebagai berikut:

- Zona inti terjadi pada tahun 2006 sebesar $1.473 .572,4$ ton/tahun

- Zona penyangga terjadi pada tahun 2006 sebesar 705.096,4 ton/tahun

- Zona transisi terjadi pada tahun 1991 sebesar 1.036.069,6 ton/tahun

3. Secara umum nilai NDVI untuk zona inti lebih besar dibandingkan dengan zona penyangga, dan zona transisi memiliki nilai NDVI terkecil. Hal yang sama juga terjadi pada nilai fAPAR yang diturunkan dari nilai NDVI.

4. Nilai NPP mengikuti pola dari nilai NDVI dan fAPAR.

5. Nilai NPP yang menggambarkan kondisi vegetasi di Cagar Biosfer Cibodas menunjukkan bahwa nilai NPP yang tinggi merupakan kawasan dimana terdapat luasan dan kondisi vegetasi yang baik, karenanya diharapkan dengan adanya penelitian ini atau penelitian lanjutan nantinya, usaha konservasi lahan dan hutan di wilayah Cagar Biosfer Cibodas dapat lebih terarah.

\section{DAFTAR PUSTAKA}

Balai Besar Taman Nasional Gunung Gede Pangrango. 2012. Selama 12 tahun penutupan lahan TNGGP semakin baik [terhubung berkala]. http://www. gedepangrango.org/selama-12-tahun-penutupanlahan-tnggp-semakin-baik/. [10 November 2011].

Churniawan T.H. 2008. Pendugaan net primary production (NPP) menggunakan netpro v1.1 (Studi kasus Taman Nasional Lore Lindu Sulawesi Tengah Tahun 2001 dan 2005) [Skripsi]. FMIPA-IPB. Bogor.

Ibrom A., A. Oltchev, T. June, T. Ross, H. Kreilein, U. Falk, J. Merklein, A. Twele, G. Rakkibu, S. Grote. 2007. Effects of land-use change on matter and energy exchange between ecosystems in the rain forest margin and the atmosphere. Environmental science and engineering 2:461-490.

June T., A. Ibrom, G. Gravenhorst. 2006. Integration of NPP semi mechanistic - modelling, remote sensing and GIS in estimation CO2 absorption of forest vegetation in Lore Lindu National Park. BIOTROPIA 13:22-36.

Lestariningsih S. 2006. Changes in land cover and net primary production of Gunung Walat Educational Forest, Sukabumi in 1995 and 2004 [Skripsi]. FMIPAIPB. Bogor.

Lillesand, T.M. and W.R. Kiefer. 1997. Penginderaan jauh dan interpretasi citra. Diterjemahkan : Dulbahri, Prapto Suharsono, Hartono, Suharyadi. Gajah Mada University Press. Yogyakarta.

Man and Biophere Indonesia. 2011. Cagar Biosfer Indonesia. [terhubung berkala]. http://www.mabindonesia.org/tentang.php?i=biosfer. [10 Mei 2011].

Rusmayadi G., Handoko, Y. Koesmaryono, D.H. Goenadi. 2008. Pemodelan tanaman Jarak Pagar (Jatropha curcas L.) berbasis efisiensi penggunaan radiasi surya, ketersediaan air, dan notrogen. Jurnal Agromet 22: 31 - 48 .

Soedjito H. 2004. Pedoman pengelolaan cagar biosfer Indonesia. Panitia Nasional MAB Indonesia, LIPI. Jakarta.

Suheri. 2003. Studi perubahan penutupan lahan di daerah penyangga Taman Nasional Gunung Gede Pangrango menggunakan sistem infomasi geografis [Skripsi]. Fakultas Kehutanan-IPB. Bogor.

Supeni A. 2006. Estimation of net Pro 1.0 Model [Skripsi]. FMIPA-IPB. Bogor.

UNESCO. 2003. Biosphere Reserves. On ground testing for sustainable development. Graha Info Kreasi. Jakarta. 